\title{
Urban speleology applied to groundwater and geo-engineering studies: underground topographic surveying of the ancient Arca D'Água galleries catchworks (Porto, NW Portugal)
}

\author{
H.I. Chaminé ${ }^{1,8}$, M.J. Afonso ${ }^{1,8}$, P.M. Robalo ${ }^{2}$, P. Rodrigues ${ }^{2}$, C. Cortez ${ }^{2}$, F.A. Monteiro
}

Santos $^{3}$, J.P. Plancha ${ }^{3}$, P.E. Fonseca ${ }^{4}$, A. Gomes ${ }^{5}$, N.F. Devy-Vareta ${ }^{5}$, J.M. Marques ${ }^{6}$, M.E. Lopes ${ }^{1}$, G. Fontes ${ }^{7}$, A. Pires ${ }^{8,1} \&$ F. Rocha ${ }^{8}$

\begin{abstract}
:
Chaminé H.I., Afonso M.J., Robalo P.M., Rodrigues P., Cortez C., Monteiro Santos F.A., Plancha J.P., Fonseca P.E., Gomes A., Devy-Vareta N.F., Marques J.M., Lopes M.E., Fontes G., Pires A. and Rocha F. 2010. Urban speleology applied to groundwater and geo-engineering studies: underground topographic surveying of the ancient Arca D’Água galleries catchworks (Porto, NW Portugal). International Journal of Speleology, 39 (1), 1-14. Bologna (Italy). ISSN 0392-6672.

The Porto settlement (Northwest Portugal, Iberian Peninsula) was originally built in the twelfth century and has been developed on granitic hill slopes of the Douro riverside, being one of the oldest cities in Europe. In the urban area of Porto, the second most important city of the Portuguese mainland, there is a population of about 216,000 inhabitants. This study highlights the importance of urban speleological mapping applied to groundwater and geo-engineering studies. All the water that flows from the so-called Paranhos or Arca D'Água springs is captured by catchwork galleries and their utilization date back around 1120 AD. Paranhos spring galleries catchworks (c. 3,3 km extension and a $-21 \mathrm{~m}$ below ground level) was one of the main water supplies to Porto City for more than six centuries and, nowadays, these waters are still appropriate for irrigation uses. Topographical, geological, geophysical and hydrogeological data were collected and interpreted, allowing the definition of a hydrogeotechnical zoning. All these features were mapped and overlaid using GIS mapping techniques. This multidisciplinary approach offers a good potential for reliable urban speleological and geo-engineering studies of Arca D'Água site.
\end{abstract}

Keywords: urban speleology, groundwater, catchwork galleries, water supply, NW Portugal.

Received 5 August 2009; Revised 12 October 2009; Accepted 1 December 2009

\section{URBAN GEOSCIENCE AND GROUNDWATER}

Many urban planners in developing countries are turning to their potentially valuable groundwater resources as a water supply source because the available surface water is very polluted, and groundwater is seen as a reliable and easily accessible

1 Laboratório de Cartografia e Geologia Aplicada (Labcarga), Departamento de Engenharia Geotécnica, Instituto Superior de Engenharia do Porto, Rua do Dr. António Bernardino Almeida, 431, 4200-072 Porto, Portugal, hic@isep.ipp.pt

2 Associação dos Espeleólogos de Sintra (AES), Sintra, Portugal. 3 Departamento de Engenharia Geográfica, Geofisica e Energia (CGUL-IDL), Universidade de Lisboa, Portugal.

4 Departamento de Geologia (CeGUL), Universidade de Lisboa, Portugal.

5 Departamento de Geografia (CEGOT), Universidade do Porto, Portugal.

6 Departamento de Engenharia de Minas e Georrecursos (CEPGIST), Instituto Superior Técnico, IST, Lisboa, Portugal.

7 Águas do Porto, E.M., Porto, Portugal.

8 Centro GeoBioTec (Grupo de Georrecursos, Geotecnia e

Geomateriais), Universidade de Aveiro, Portugal. substitute. Nevertheless, whilst groundwater sources are being tapped for water supply, at the same time the bedrock is used as a filtering medium for human waste and grey-water disposal. Since water is an integral part of the environment, the hydrogeology of cities should be seen as a vital key issue in all successful urban planning. A settlement cannot exist without fresh water and obtaining it in sufficient quantity and good quality, both for domestic and industrial use, is a primary civic service (e.g., Legget, 1973; McCall et al., 1996). The significant role that groundwater plays in the urban cycle is well established in many countries around the world, both in terms of quantity and quality (Chilton, 1997, 1999; Lerner, 2004).

Urbanization has a deep and often detrimental impact on the hydrological cycle at different scales. The urban subsurface includes a network of pipes, conduits and other ground structures that modify the natural hydraulic conductivity of the geological materials. Those infrastructures were dug to facilitate transportation, drainage, sewerage and to provide a water supply system for the population. Harmful impacts on groundwater quality in urban centers can occur from numerous point and diffuse sources. The 
impacts can derive from industrial sources (accidental and/or deliberate), pipe infrastructure, impacts related to declining or rising water tables, land use and storm-water impacts, and so on. Aquifers characterized by the presence of abundant, but very vulnerable, groundwater are in many cases located below major cities, where the poor knowledge of aquifer characteristics, uncontrolled exploitation and indiscriminate effluent and waste disposal practices contribute to groundwater resources degradation (e.g., Legget, 1973; Chilton, 1997, 1999; Foster et al., 1999; Petri et al., 2007).

Urban geology or more broadly urban geoscience can be described as an interdisciplinary field in geo- and socio-economic sciences addressing Earthrelated problems in urbanized areas (Legget, 1973; CERF, 1994; McCall et al., 1996). Apart from the more traditional disciplines such as petrography, geochemistry, structural geology and geomorphology, some applied interdisciplinary fields such as hydrogeology, engineering geology, applied geophysics, geological hazards and environmental geotechnics play a dominant role in urban geosciences. Urban geosciences can provide to engineers, planners, land decision makers, and the general public sensitive to Earth Sciences, significant information required for sound regional planning in densely populated areas. The increasing worldwide pressure on groundwater resources under conditions of global anthropogenic and climatic change often requires an integrated multidisciplinary approach to address the scientific issues involving water resources. Therefore, all these disciplines have to be integrated with a thorough knowledge of the regional and local geological conditions, being more suitable for the human communities that make use of water and land in urban areas (Mulder et al., 2001).

Over the centuries, acquisition of water from rivers, lakes, wells or springs has been a daily task for mankind. The fresh water supply network emerged along the construction of cities and villages. The Romans, strongly rooted in Iberian Peninsula, developed an organized system of aqueducts, fountains, siphons, cisterns, sewers, channeling water to create public bath sites and temples dedicated to gods of healing (e.g., Ashby, 1935; de Oliveira Marques, 1972; Hodge, 1992; Koloski-Ostrow, 2001; Petri et al., 2007; Parise et al., 2009). In the middle Ages, water was distributed by human intervention, partly by private water carriers. After the empirical methods of the nineteenth century, the first modern societies with regard to water supply were arising (Bouguerra, 2005; Garden, 2005). In the past, public fountains were a social assembly point, while people fetched water for drinking or bathing.

The present study, developed on the so-called Paranhos or Arca D’Água spring galleries (Porto, NW Portugal), describes some aspects about the geoengineering mapping of the ancient granitic galleries catchworks, specially referred to underground topographical constraints. The Arca D'Água galleries and shafts although being for a long time known by the technical and scientific community (e.g., Gavand, 1864; Bourbon e Noronha, 1885; Carteado Mena, 1908; Fontes, 1908), lacked, as much as we know, an actualized and detailed underground topographic map. The topographical surveys were conducted to be the fundamental support for the groundwater and geoengineering studies performed at Arca D’Água spring galleries catchworks, in Porto. This interdisciplinary methodology has been valuable to improve our hydrogeological understanding of the ancient network groundwater galleries catchworks of Porto (figure 1).

\section{REGIONAL FRAMEWORK FROM PORTO URBAN AREA}

\section{Historical outline}

Porto urban area and its sprawling suburbs are the second largest in Portugal, having a population that approaches one million. The city of Porto has an area of $41,3 \mathrm{~km}^{2}$ and an estimated population of around 216,000 inhabitants (INE, 2008). It's one of the oldest cities in Europe and is surrounded by an outstanding urban landscape.

The earlier settlements, date back at least to the early fifth century BC since the days of Visigoths and Suevians and grew up near the rugged north bank of the Douro River (de Oliveira Marques, 1972). The Romans established a village there in the first century $\mathrm{BC}$, under the name of Portus (Port), which became very important as an administrative and trading centre. The so-called Portus Cale (later Portucale and, in its non-Latin form, Portugal) was previous designation for the Porto and Gaia settlements (Rebelo da Costa, 1788). Although it had changed hands more than once during the Moorish occupation in the Iberian Peninsula, the Arabs were evicted definitively in $868 \mathrm{AD}$, after which it remained Christian. Porto became an important settlement since the twelfth century and has been developed along the granitic hillsides overlooking the mouth of the Douro River. The architectural and patrimonial attributes of its old neighborhoods led the Historic Centre of Porto to be recognized by UNESCO as World Heritage Site in 1996.

\section{Geological and geomorphological background}

The northwest portion of the Iberian Massif is transacted by a regional major displacement zone, the Porto-Tomar-Ferreira do Alentejo shear zone (Chaminé et al., 2003a,b; Ribeiro et al., 2007). The segment Porto-Coimbra-Tomar is a regional strikeslip fault zone that acts as the boundary between two major geotectonic domains of the Iberian Massif: the Portuguese northernmost domain of the so-called Ossa-Morena Zone and the Central-Iberian Zone (Chaminé et al., 2003b).

The Porto urban area is located along the PortoCoimbra-Tomar shear zone and is enclosed within the so-called Western Iberian Line, a tectonic corridor stretching out from Finisterre (Galicia, NW Spain) to Tomar region (Chaminé et al., 2003b; Gomes et al., 2007). The regional tectonic framework comprises a crystalline fissured basement complex of highly 


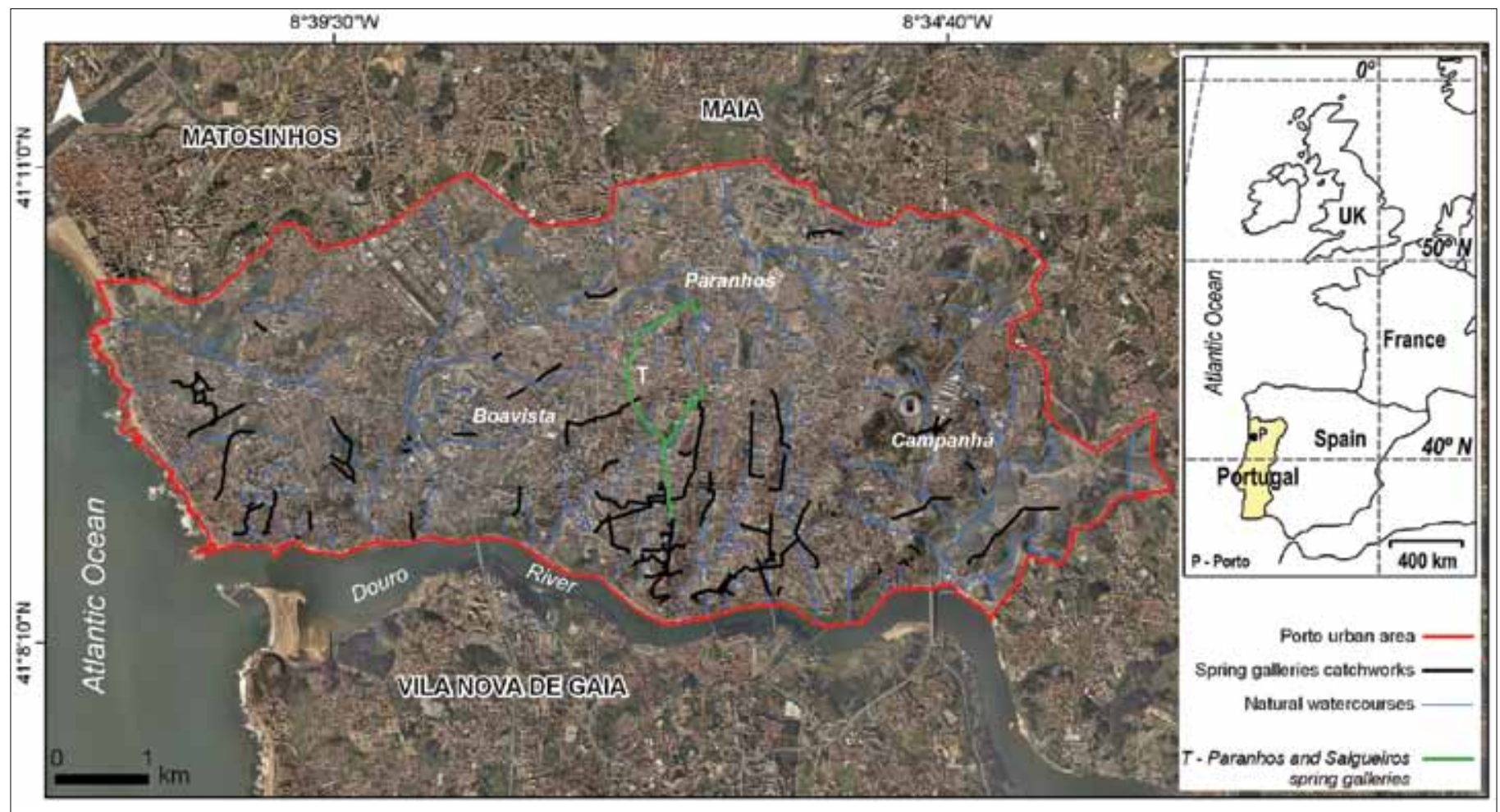

Fig. 1. Satellite image of Porto urban area (NW Portugal, Iberian Peninsula) and the main ancient spring galleries catchworks network (adapted from Amorim \& Pinto, 2001; COBA, 2003)

deformed and overthrusted Late Proterozoic/Paleozoic metasedimentary and granitic rocks (e.g., Sharpe, 1849; Carrington da Costa, 1938; Almeida, 2001; Chaminé et al., 2003a, and references therein), figure 2. It defines some main orientations: NNW-SSE and NE-SW lineaments are dominant, with subordinate ENE-WSW; the predominant dip of the discontinuities is vertical to sub-vertical. The geomorphological setting of the Porto region consists of a littoral platform characterized by a quite regular planation surface dipping gently to the west. This platform was cut by the Douro River in a steep-walled valley with sharp and high slopes that constitutes the socalled riverside downtown with its typical entrenched morphological context.

\section{DESCRIPTION OF THE ARCA D'ÁGUA SITE}

In Porto municipality, the public fountains were installed at least since c. 1390. Otherwise, the most oldest historical know record about Arca D’Água springs (previous called Arca das Três Fontes [Three Fountains Masonry Reservoir) for public use dates back to 1120 (Fontes, 1908; Amorim \& Pinto, 2001). For more than six centuries, the fresh water supply of Porto was possible through fountains that were fed by numerous springs (e.g., Sousa Reis, 1867, Bourbon e Noronha, 1885; Fontes, 1908; CMP, 1932; Alves, 2005). During the centuries, several underground galleries and tunnels were excavated throughout the granitic rock mass to gather the groundwater for public use (figure 3).

The Arca D'Água spring galleries catchworks constituted one of the main ancient water supplies to the population of Porto City. All the water that flows from the Arca D'Água [Water Masonry Reservoir] is captured by an intricate network of catchworks galleries, which has been used to supply domestic fresh water since 1607 (Bourbon e Noronha, 1885; Fontes, 1908). It was a fragile water conduit, full of obstructions and leakage and was therefore subject to repairs. In fact, the priest $D$. Balthazar Guedes, the founder of College for Orphans, reports in his chronicles, on 17 October 1669, that he was charged (on 1666) by the Porto municipal authorities to supervise the implementation of the repair works on Paranhos underground stone pipes and masonry aqueducts (Silva, 2000, 2004). Nowadays, due to the quality degradation, the groundwater is no more used for public purposes.

The natural conditions of most groundwater systems located in Porto urban area had not been seriously degraded by human interference until the early nineteenth century. These resources were utilized only locally, and the negative effects were generally compensated by natural recharge. However, during the late nineteenth century and early twentieth century the resources have become progressively more endangered, both in quantity and in quality (Bourbon e Noronha, 1885; Ferreira da Silva, 1889; Fontes, 1908; CMP, 1932; Lima, 1936). Sewerage arrangements were inadequate and often fetid water was fed into the water supply. Since then, several studies were developed, particularly related to sanitary analysis for the potable water supply (e.g., Bourbon e Noronha, 1885; D'Andrade Junior, 1895; Carteado Mena, 1908; Fontes, 1908; Guedes, 1917). A remarkable aspect of its importance is shown by the fact that during the eighteenth century there were close to 100 public fountains in Porto (Rebelo da Costa, 1788).

At that time water was provided using a new 


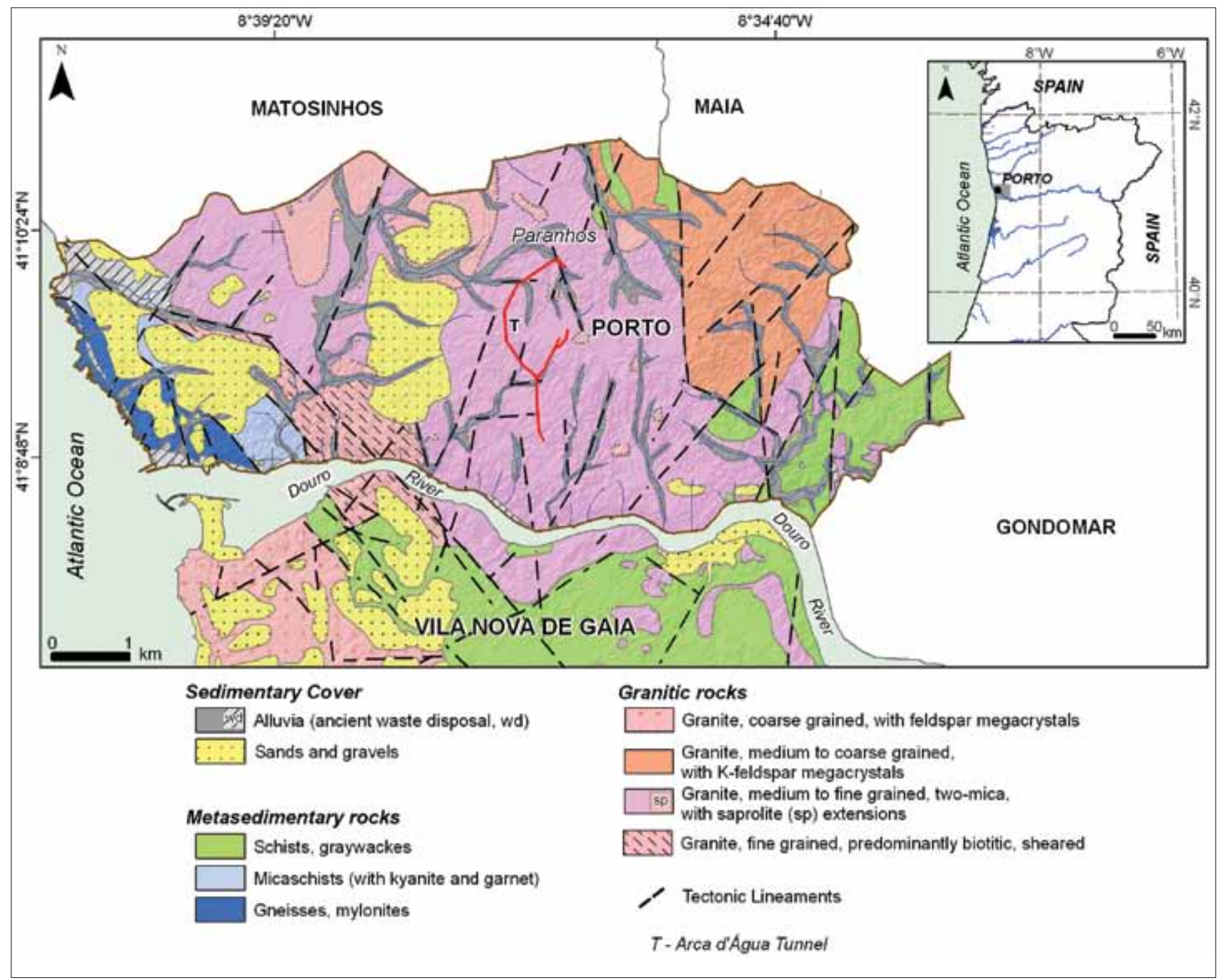

Fig. 2. Regional geological setting from Porto urban area (revised from Carríngton da Costa \& Teixeira, 1957; Pereira et al., 1989; COBA, 2003; Chaminé et al., 2003a and unpublished geological cartography (Porto - V.N. Gaia sector) by H.I. Chaminé, A.Gomes, P.E. Fonseca).

system of masonry aqueducts and metal pipes. At considerable costs, an adequate sewage system was built with excellent sewers leading to land purchased by the city for safe disposal. These works were mainly undertaken between 1882 and 1887. Since then advances in domestic supply to most modern homes have significantly reduced the need for public drinking fountains in cities.

The water supply to the city of Porto was contracted in 1882 with a French private company, owned by the Compagnie Générale des Eaux pour l'Étranger. The French company invested very little in the waterworks, and its response to the difficulties generated by the First World War was lowering the quality of the provided service. In Porto, the Companhia das Águas do Porto was municipalized in 1927 (e.g., Amorim \& Pinto, 2001; Silva, 2004; Silva \& Matos, 2004). It was a long process, which started in 1920 with the creation of a committee to analyze the water supply conditions in the urban area of Porto. The municipality paid an indemnity to the French company to take over the waterworks. Public pipes, aqueducts, reservoirs and fountains remained under city control and the water was used both for municipal services consumption and for providing the population with public fountains. Only provision of piped water to households by Porto City council was forbidden. After the 1920's, with respect to municipal control over the water supply, both public and private infrastructures were consolidated under unified management (Silva \& Matos, 2004).

\section{MATERIAL AND METHODS}

The underground constraints of the Porto groundwater systems, namely Arca D’Água spring galleries catchworks, were assessed on a multidisciplinary urban geo-environmental approach. The present study integrated several techniques: urban speleology, geomorphology, applied geology, hydrogeology and applied geophysics. All cartographic subjects were further refined through the application of Geographical Information System (GIS) tools (Johnson, 2009) and using methodologies and techniques proposed, namely, by IAEG (1981), CFCFF (1996), Day (2002), Assaad et al. (2004) and ISRM $(1978,1981,2007)$.

For this purpose, the following steps were taken:

1) Underground topography and cave surveying in order to describe the cartographic aspects of the ancient granitic galleries catchworks. Urban speleological 


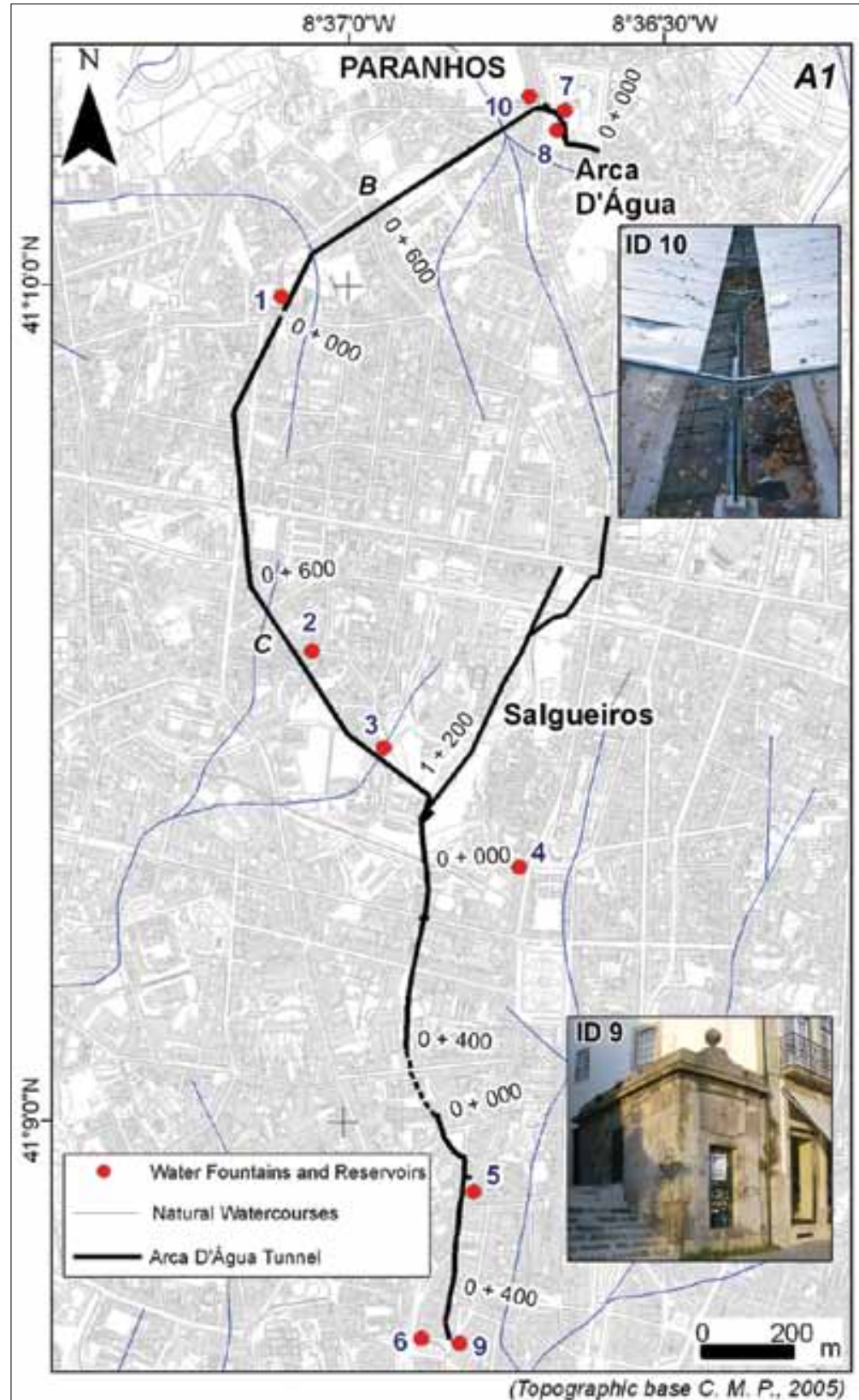

(Topographic base C. M. P. 2005)

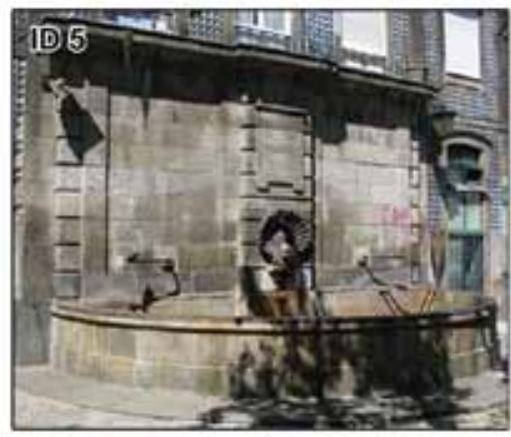

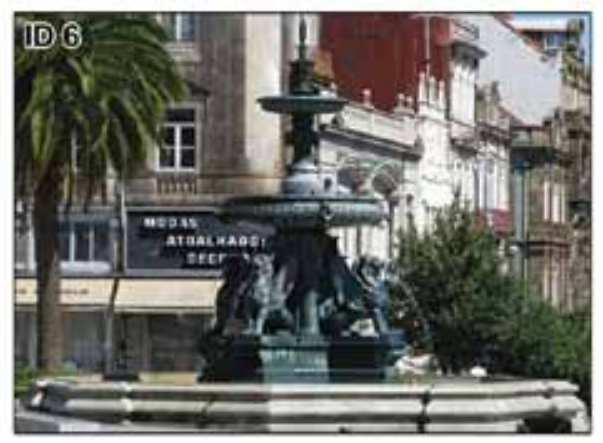
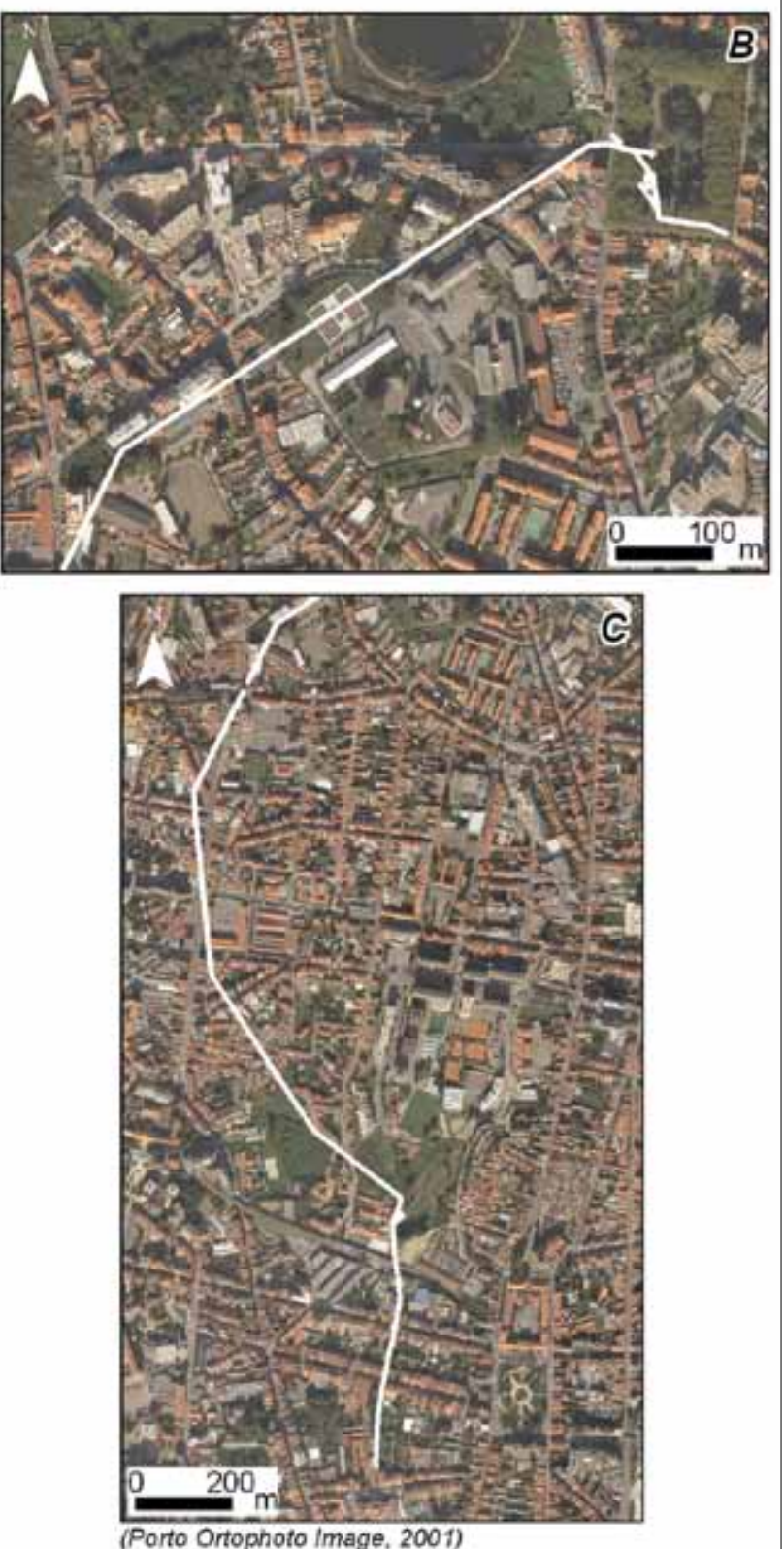

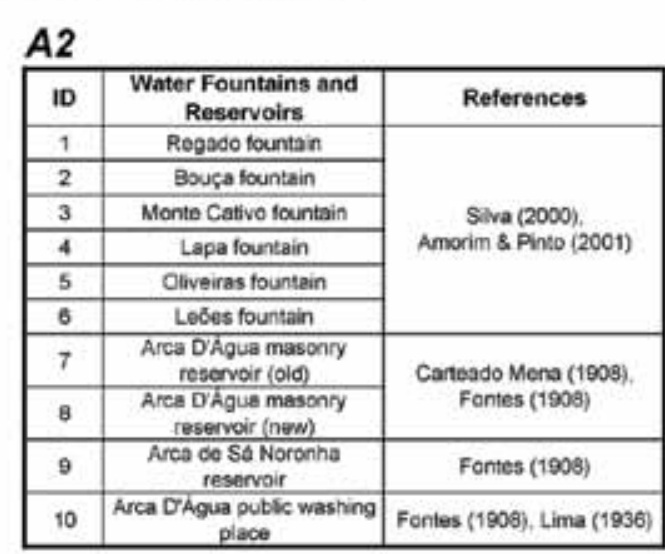

Figure 3. General features from Paranhos galleries network (A1): Paranhos tunnel framework and location of the main water fountains and reservoirs fed by Paranhos spring waters; (A2): water fountains, reservoirs and public washing place designations; (B) and (C) Paranhos Tunnel alignment and highly urbanization area.

and mining topography techniques were used. The grading for a cave line survey and for recording cave passage details proposed by the British Cave Research Association (BCRA) was followed (Day, 2002). The main equipments used for the urban speleological surveys performed at the Paranhos narrow spring galleries catchworks were (AES, 2008): a) Suunto Tandem compass and clinometer, a liquid-filled precision instrument to measure directions, vertical angles and slopes, with great speed and accuracy; b) 
50m fibber-glass tape class III and a laser range meter Disto Hilti, with a accuracy $\pm 2 \mathrm{~mm}$, were used to the measurement of distances. Otherwise, on the large spring galleries catchworks and ground were used an electronic Total Station PowerSet 2000 Sokkia, with tree tripod methods to observe the transverse loops on the large galleries. Distance was read to the nearest centimeter and angles to the nearest degree. Survey stations were placed temporary mainly on basement of granitic rock mass gallery or gutter masonry pipe. Occasionally, the survey stations were marked with dye spots. The figure 4 shows several features from the underground topographic constraints and urban speleological techniques performed during the gallery surveys.

2) Surface geomorphological and geological, hydrogeological and geophysical surveys were performed regarding the general framework of the galleries catchworks. The fieldwork surveys allowed to identify major tectonic accidents responsible for groundwater circulation paths and to assess lithological and structural heterogeneities. A high-precision GPS
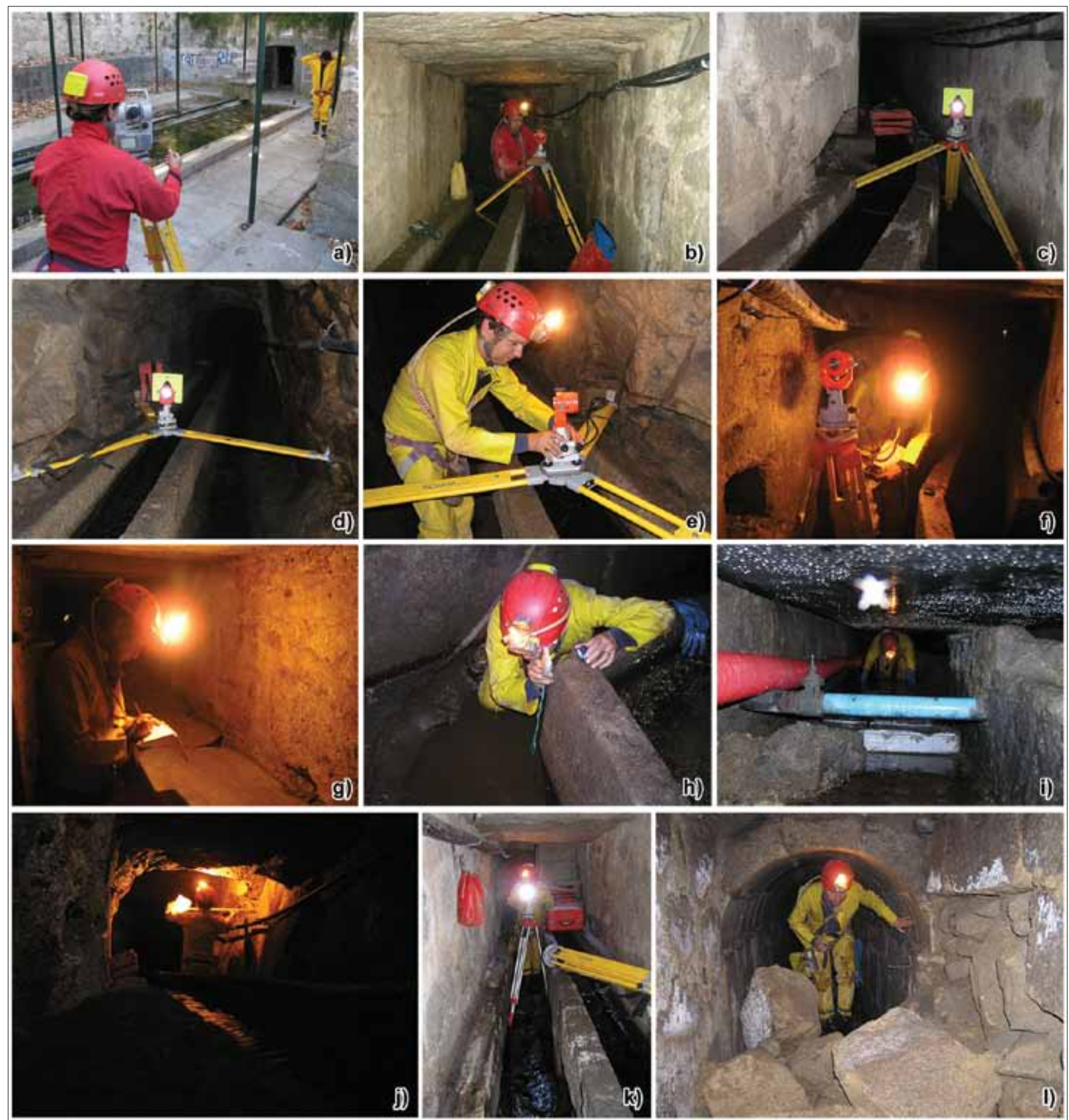

Fig. 4. Underground topographic constraints and urban speleological techniques performed during the gallery surveys (a. to e., k. - electronic total station survey with tree tripod methods to observe the transverse loops on the large galleries and surface; f., g. - topographic data recording; $h$. - compass survey technique; i. - exploration and inspection of narrow gallery; j. - caving measurements with fibber-glass tape; l. - inspection of underground gallery, resulting in the partial interruption of gallery wall). 
(Trimble ${ }^{\circledR}$ GeoExplorer) was utilized for the surface fieldwork surveys. Two dipole-dipole profiles were carried out in the Arca D'Água Garden in order to detect the underground cavities. The dipole-dipole resistivity array has been successful used in cave detection (e.g., Richard, 1977; El-Qady et al., 2005; Monteiro Santos $\&$ Andrade Afonso, 2005). In this array, two current electrodes (AB) are kept fixed while the potential electrodes (MN) are moved collinearly to the current ones. The spacing between current electrodes and potential electrodes is a multiple of the electrode spacing $a$. The depth of penetration is a function of the distance a (Edwards, 1977). In the present study an electrode spacing of $5 \mathrm{~m}$ was adopted in order to investigate the shallow subsurface structures. The apparent resistivity $\left(\rho_{a}\right)$ was calculated by

$$
\rho_{a}=\operatorname{\pi an}(n+1)(n+2) \frac{\Delta V}{I}
$$

where $n$ is the number of dipoles separating current electrodes from potential electrodes ( $\mathrm{n}$ level), $\Delta \mathrm{V}$ is the electrical potential difference measured between the electrodes $\mathrm{M}$ and $\mathrm{N}$ and $\mathrm{I}$ is the electrical current through the electrodes A and B;

3) Underground geological/geotechnical mapping (scale: $1 / 500$ and 1/1000) enabled characterization of the Paranhos rock mass underground area (Arca d'Água-Arca de Sá Noronha sector). For the rock mass characterization, the scanline sampling technique of discontinuities has been applied to the granitic rockmass faces. The scanline technique involves laying a tape along the length of an outcrop and determining its orientation. All the discontinuities intersected by the tape, as well as their geologic and geotechnical rock mass parameters proposed by ISRM $(1978,1981)$, were recorded. Quantitative discontinuities measurements were obtained using two principal survey methods. Geological structures were sampled from a map of the underground sections of the rock exposure, and rockmass geotechnical features were characterized using scanline surveys. Weathering grade of rock material are used following the proposal by ISRM $(1978,1981)$.

4) Description of groundwater quality, by using hydrogeochemical analysis. Hydrogeological fieldwork campaigns were performed and in situ determinations included: temperature $\left({ }^{\circ} \mathrm{C}\right), \mathrm{pH}$ and electrical conductivity $\left(\mu \mathrm{S} . \mathrm{cm}^{-1}\right)$. Sixteen sampling sites were established for hydrogeochemical evaluation. The hydrogeochemical analysis were acquired at a certified laboratory (Centro de Estudos de Águas do ISEP, Porto, Portugal). All water samples have been analyzed for major element concentration

\section{RESULTS AND DISCUSSION}

\section{Underground topography and urban geophysics}

Among ancient techniques, constructing a tunnel between two distant points involves mastering several scientific fields, including topography, engineering, architecture, hydraulics, and geology (e.g., Frumkin \& Shimron, 2006; Brick, 2009). We performed a comprehensive study of Arca D'Água tunnels, comprising over 38 vertical shafts in the Porto granite bedrock. The primary gallery surveyed of Paranhos tunnel is 3,289 $\mathrm{km}$ long and has a maximum depth of $-21 \mathrm{~m}$ below ground level (b.g.1.), it goes from Praça de 9 de Abril (Arca D'Água site) to Praça de Gomes Teixeira (Arca de Sá Noronha site). The tunnel has an internal diameter of $2,20 \mathrm{~m}$, with a maximum cover of $21 \mathrm{~m}$ and a minimum of $1 \mathrm{~m}$. A total of 77 survey legs were made (AES, 2008).

Reducing long tunnels into short segments allowed easy underground connection and manmade intermediate ventilation shafts. This can be systematized into three main groups: i) masonry shafts; ii) rocky shafts; and iii) rocky-saprolite shafts. The shafts resemble vertical tubes in shape, tapering downward into tunnel under unconfined conditions. While active, such shafts act as vertical conduits carrying vadose water down, towards the regional water table. In the studied tunnel, individual shafts are commonly some $21 \mathrm{~m}$ deep maximum.

The Paranhos tunnel can be subdivided into three main sections and is mainly traced in the densely populated area of Porto. The first section stretches 948 m from Praça de 9 de Abril (or Arca D’Água Garden) to Rua Nova do Regado, with 3 exit/entrance gates and 9 shafts. This section has a maximum cover of $20 \mathrm{~m}$ and a minimum of $1 \mathrm{~m}$ close to the end of the gallery. The second section is $1817 \mathrm{~m}$ long and runs from Rua Nova do Regado to Rua dos Bragas, with 3 gates, 19 shafts and a maximum overburden of $21 \mathrm{~m}$. Finally, the third section has $524 \mathrm{~m}$ of length, from Rua dos Bragas to Praça de Gomes Teixeira (Arca de Sá Noronha), with 3 main exit doors, 10 shafts and a maximum cover of $9 \mathrm{~m}$. The BCRA cave surveying standards, the most used in Europe, were applied in Paranhos tunnel. The surveys should reach for the section one and two of the Paranhos tunnel the standards of BCRA grade XD (with the exception of the first $107 \mathrm{~m}$ that is grade $5 \mathrm{C}$ ). The surveys in the third section achieve the grade 5D. Figure 5 illustrates several longitudinal cross-sections of the topographic survey.

A geophysical survey was applied aiming to detect the presence of caves and voids below the surface. Figure 6 (lines L1_A, L2_B) shows the apparent resistivity pseudosection obtained at lines 1 and 2, respectively. The line 2, carried out to the North of the main structure (tunnel) does not show any evidence of anomalous structure in depth. In opposition, line 1 shows evidences of two anomalous structures: one at the beginning of the profile and a second one approximately at the middle of the profile. The resistivity models obtained by inversion (Monteiro Santos et al., 2007) of the dipole-dipole data are showed in Figure 6 (lines L1_B and L2_B). In the model corresponding to line 2, resistivity values decrease with depth suggesting more weathered rocks in depth. As the air-filled tunnel has a near-infinite electrical resistance compared to the environmental rocks, it will produce readily recognizable anomalies. The resistivity model obtained by inversion of the line 2 data shows two high-resistivity anomalies that can be correlated with the old (at the beginning of the profile) and the new Arca D'Água masonry reservoirs (in the central part of the profile).

Geo-engineering and hydrogeological constraints

The description of the underground area $(\mathrm{ca} .3,3 \mathrm{~km}$ 


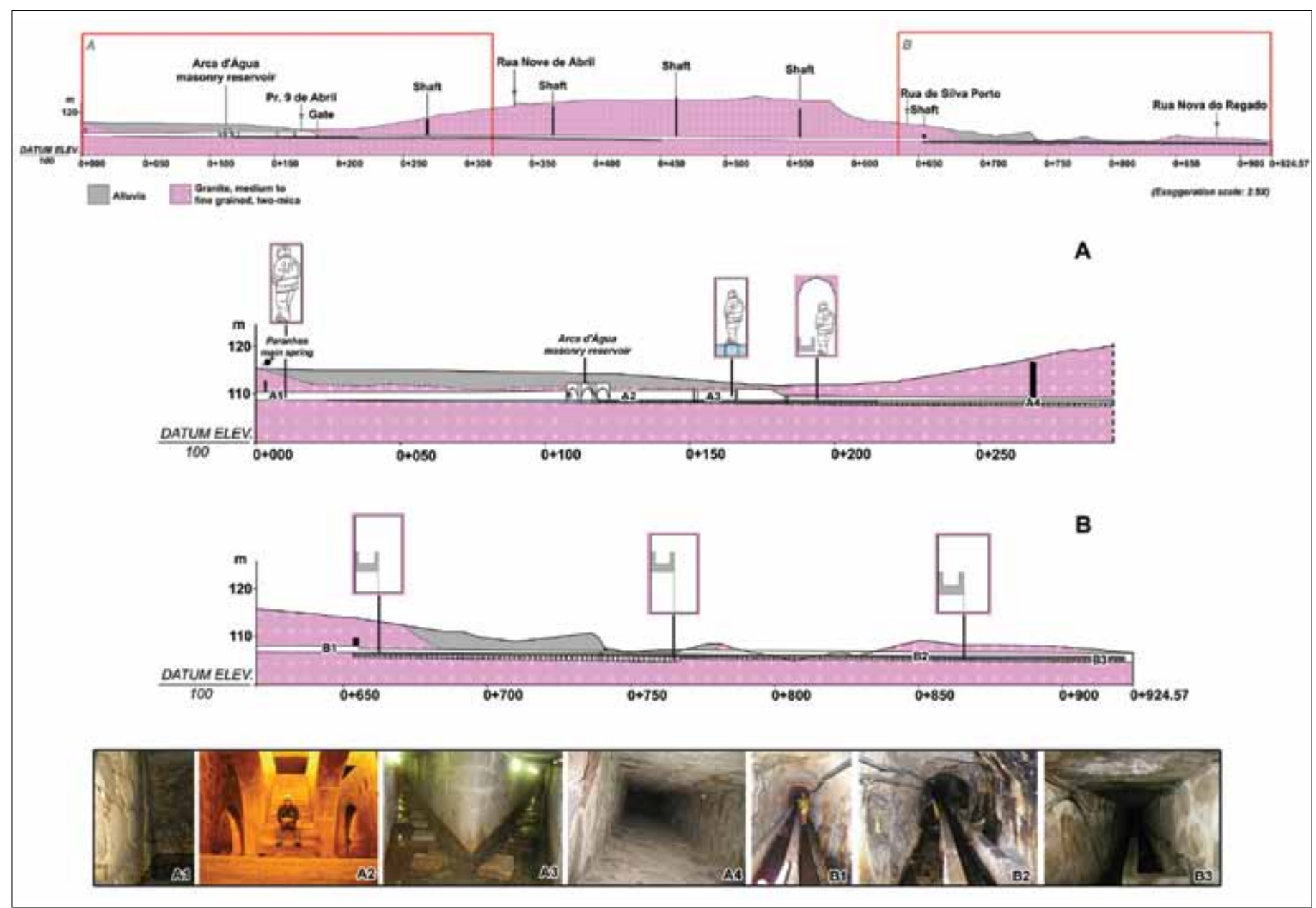

Fig. 5. Longitudinal cross-sections of the topographic survey along the first section of Paranhos tunnel (Praça de 9 de Abril to Rua Nova do Regado): an example from underground speleological survey (A1. Paranhos main spring; A2. Arca D’Água masonry reservoir; A3. Arca D’Água bifurcation galleries; A4. ventilation shaft; B1./B2. stone-walling gallery with granite gutter pipe; B3. concrete support gallery).

long and $-21 \mathrm{~m}$ depth b.g.1.), mainly comprising granitic rocks, was done by means of subsurface geological/ geotechnical and hydrogeological mapping (scale 1:500). The local discontinuities network is intense and defines some dominant fracture sets, which trends NNE-SSW to NE-SW (namely $\mathrm{N} 15^{\circ}-35^{\circ} \mathrm{E}$, dipping $70^{\circ}-80^{\circ}$ towards NW), with a minor cross-cutting WNW-trending set. Other fault sets were also recognized with a mean orientation of NW-SE and also, a sub-horizontal set. Crush-zones of intensely fragmented granitic matrix, approximately $5-10 \mathrm{~cm}$ wide are commonly associated with the faults and shear zones.

The crystalline bedrock of the study area consists mainly of granitic rocks and sheared metagranitoids, representing the so-called Porto granite facies (s.l.), i.e., syntectonic with the third regional phase $\left(\mathrm{D}_{3}\right)$ of Variscan deformation with an isotopic age of 318 million years (Almeida, 2001). It consists of a two-mica, medium to fine grained, grayish in color, changing to yellowish when weathered and in several sectors is slightly deformed. A set of rather smallscale metagranitoid bodies were identified and they are usually closely associated with major overthrust planes. The metagranitoids are leucocratic and well foliated, which is conspicuously defined by alternating bands of micas and felsic minerals. The granite is randomly crossed by quartz and aplitic/pegmatic veins, which display much less weathering features.

The galleries provided a unique cross-section through zones of intensive weathering within two-mica granites. The granitic facies in this area is generally weathered to different grades, altering erratically from fresh-rock mass to residual soil (i.e., $\mathrm{W}_{1-2}$ to $\mathrm{W}_{4-5}$, after ISRM, 1978, 1981), showing highly variable conditions, resulting in arenization and kaolinization, which may reach depths of more than $25 \mathrm{~m}$ (e.g., Begonha \& Sequeira Braga, 2002; Gaj et al., 2003). The evolution from one weathered zone to another is neither progressive nor transitional. It is thus possible to move abruptly from a good granitic boulder rock-mass to a very weathered soil like mass (Babendererde et al., 2004). Weathered material, either transported or in situ, also occurs along discontinuities.

Almost all aquifers of this region are in fissured hard rocks and comprise a weathered material zone that may have a high thickness. This soil-like layer seems to have an important role to the recharge of the aquifers underneath (Afonso et al., 2007a). The other aquifers are related with sedimentary deposits (particularly, alluvial material constituted mainly by clayey sediments and sands) that are often found above the weathered granite due to the presence of several water courses, most of all actually covered due to the intense urbanization of the area (Gaj et al., 2003).

The water table is located $3-10 \mathrm{~m}$ above the tunnel, and roughly follows the shape of the surface topography. A large number of ancient shallow wells and hand-made water tunnels are present in the 


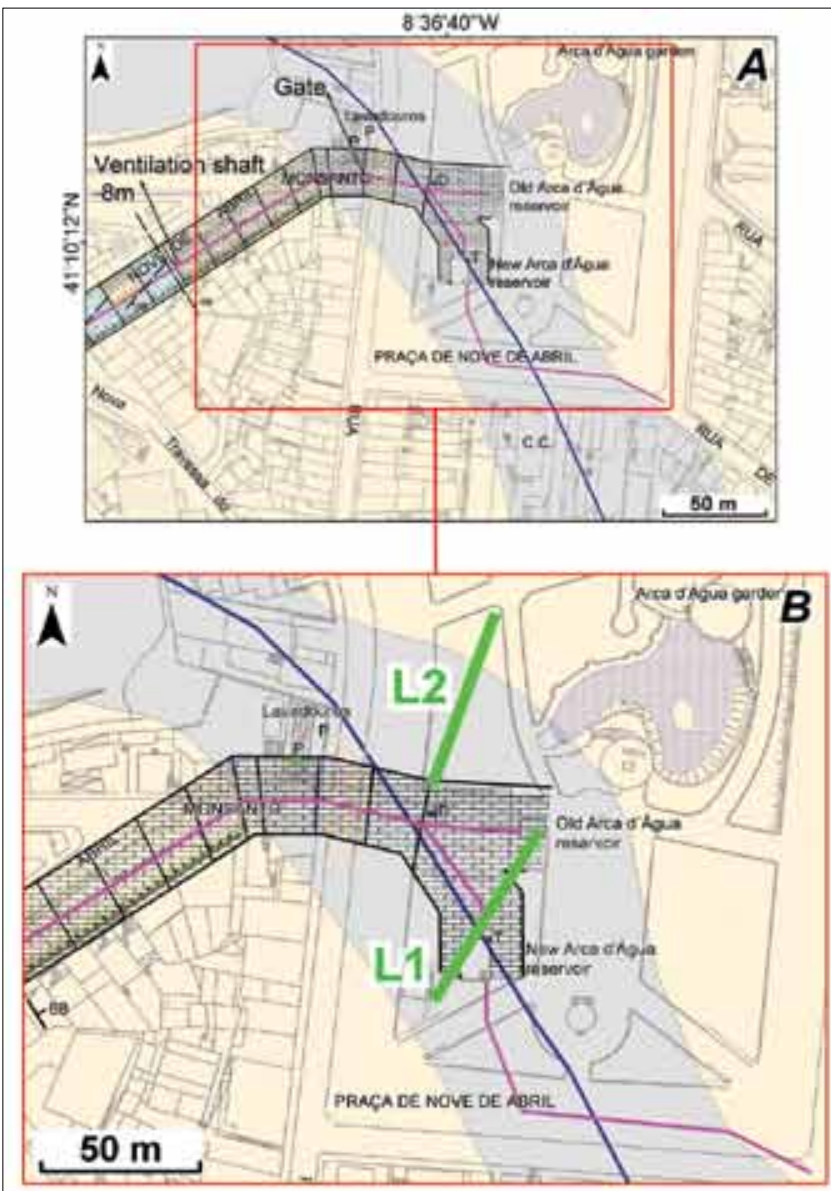

GEOLOGY
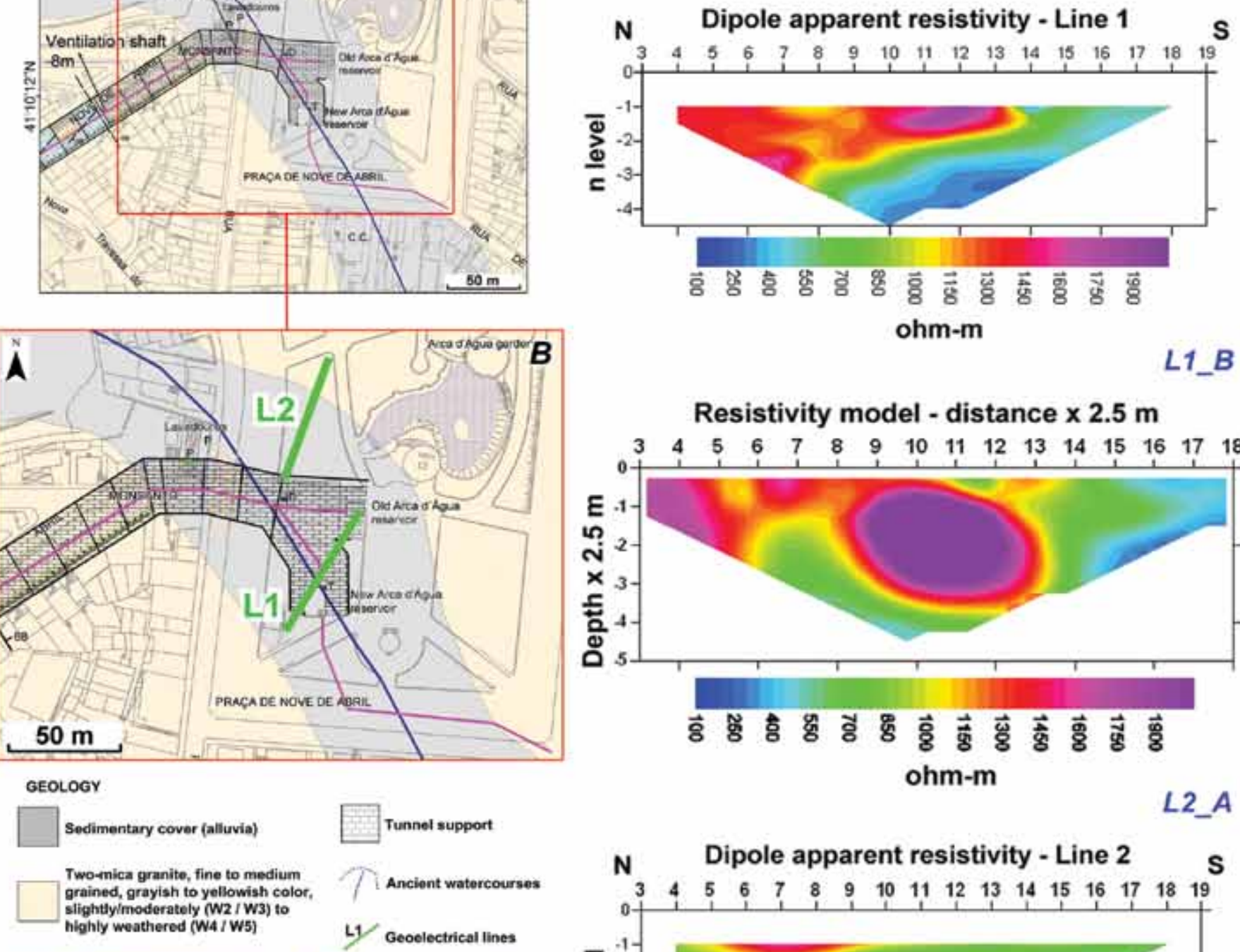

\section{Resistivity model - distance $\times 2.5 \mathrm{~m}$}

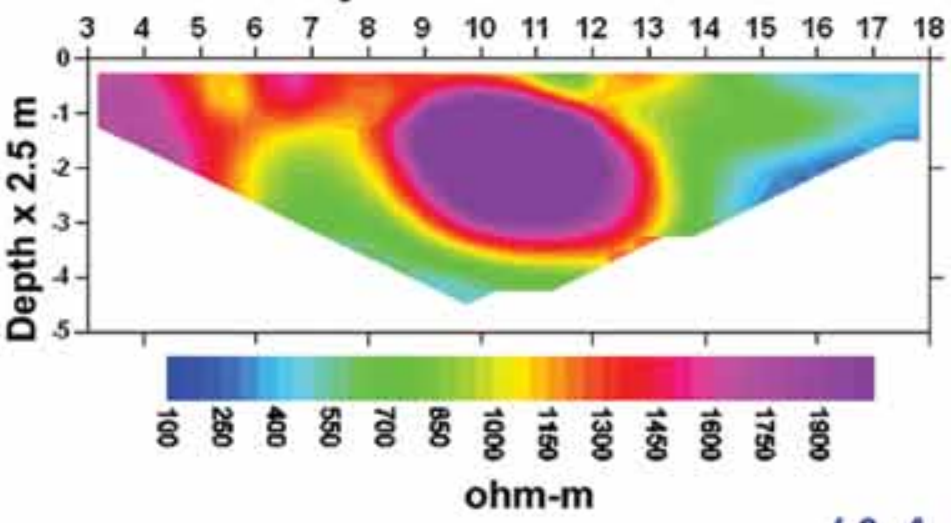

\section{L2_A}

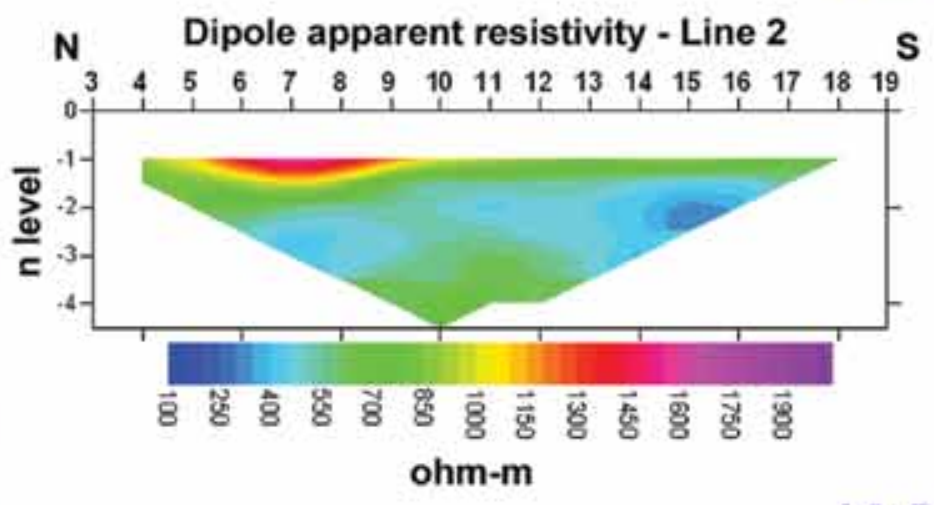

L2_B
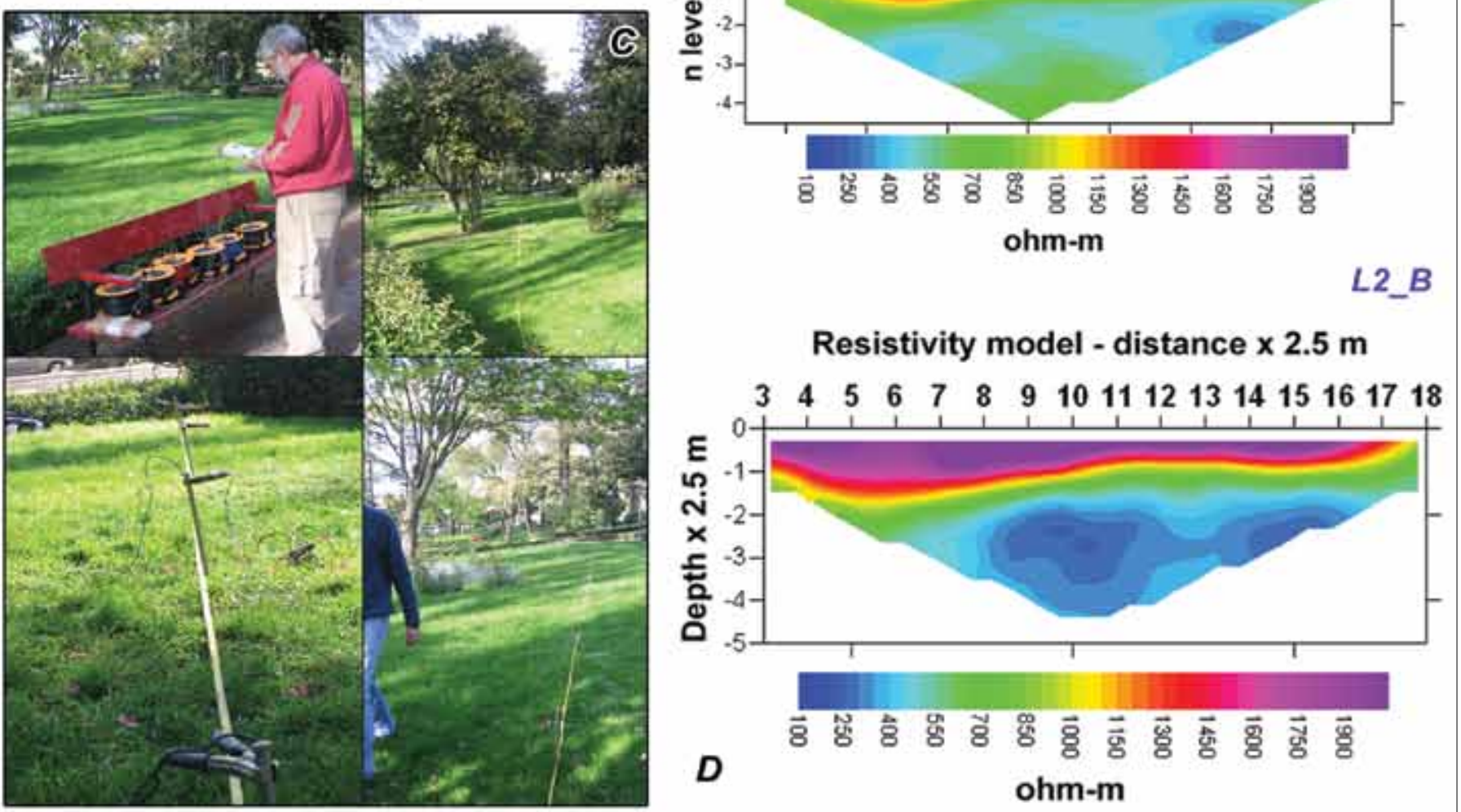

Figure 6. Geophysical survey around Arca D'Água garden. (A) Surface geology setting; (B) Location of the two geo-electrical lines, L1 and L2; (C) some aspects of the field geophysical survey; (D) L1_A: apparent resistivity pseudo-section obtained at L1; L1_B: resistivity model obtained by inversion of the dipole-dipole data for L1; L2_A: apparent resistivity pseudo-section obtained at L2; L2_B: resistivity model obtained by inversion of the dipole-dipole data for L2. 
surrounding tunnel area, which were responsible for modifying the groundwater features of the ground.

The hydrogeotechnical units in the surrounding area of the ancient Paranhos spring galleries are (some data compiled and revised from Begonha \& Sequeira Braga, 2002; COBA, 2003; Afonso et al. 2007a,b) figure 7:

1) Sedimentary deposits (recent alluvia): although these deposits may outcrop, they were not recognized inside the galleries, probably because of their small thickness along with the depth of the galleries and, particularly, by the fact that in the areas where the galleries should cross the alluvia, the tunnel is supported by stone-walling and/ or concrete. They are mainly constituted by siliceous silty and sandy soils with a low to moderate permeability $(<1.7 \mathrm{~m} / \mathrm{d})$;

2) Granitic rocks (Porto granite): this unit occurs weathered to different grades, from fresh-rock to

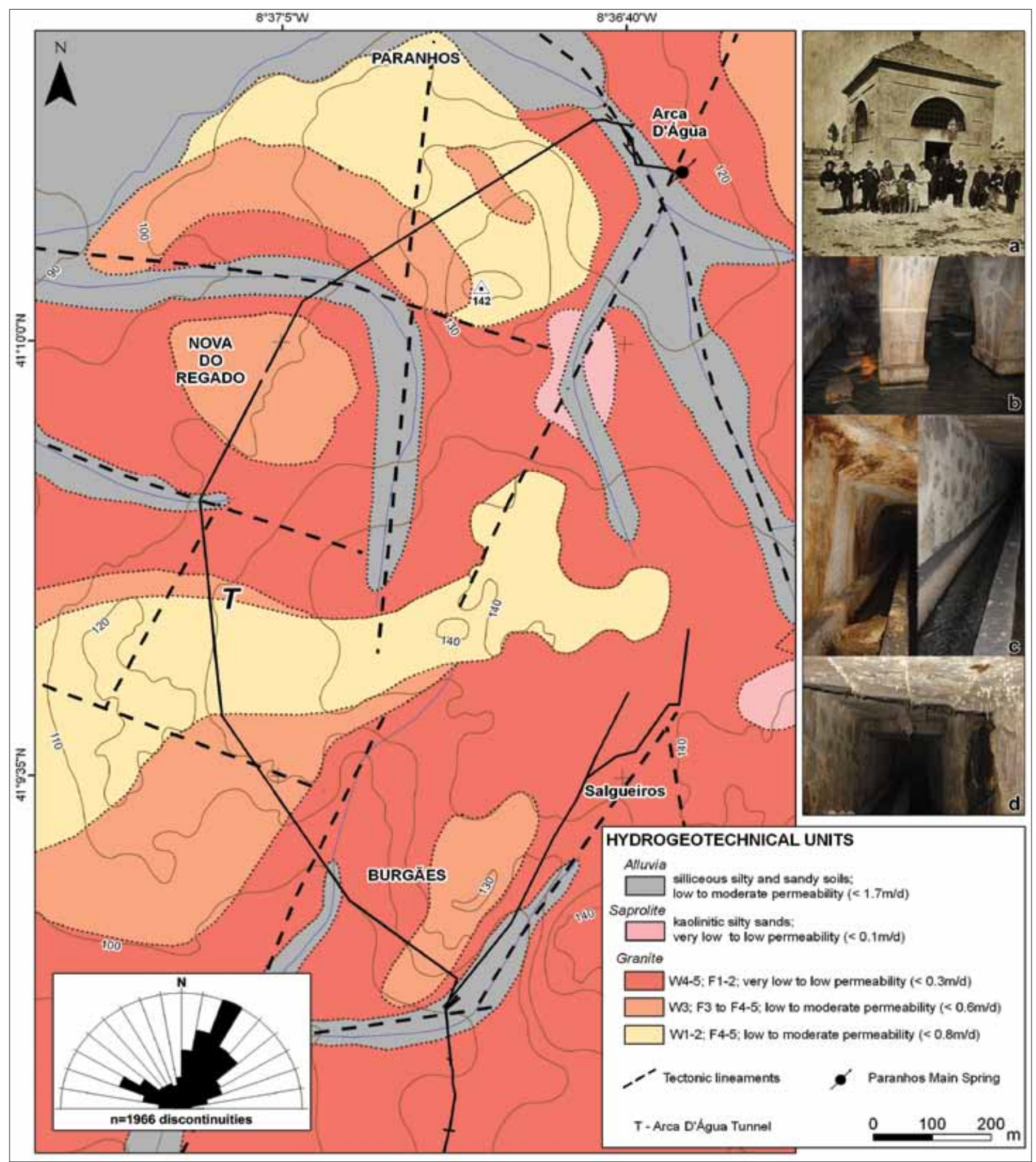

Fig. 7. Hydrogeotechnical zoning for the surrounding area of Arca D’Água spring galleries catchworks. Some aspects of Paranhos or Arca d'Água spring galleries: (a) Arca d'Água ancient fountain (after Fontes, 1908); (b) Arca d'Água masonry reservoir (c. XVI century); (c) granitic gutter pipe that collects spring waters; (d) aspect of a stone-walling and concrete support. 
slightly weathered $\left(\mathrm{W}_{1-2}\right)$ to highly weathered $\left(\mathrm{W}_{4-5}\right)$, but predominantly, moderately weathered $\left(\mathrm{W}_{3}\right)$. Its fracturing intercept degree is, dominantly, moderate $\left(\mathrm{F}_{3}\right)$ to close $\left(\mathrm{F}_{4-5}\right)$. Crushed quartz veins ranging from millimeters to several centimeters in thickness intersect the granite. The permeability of the fresh-rock to moderately weathered $\left(\mathrm{W}_{1-2}\right.$ to $\mathrm{W}_{3}$ ) ranges from low to moderate (ranging from 0.6 to $0.8 \mathrm{~m} / \mathrm{d})$. The granite highly weathered $\left(\mathrm{W}_{4-5}\right)$, wide fracturing intercept $\left(\mathrm{F}_{1-2}\right)$, with very low to low permeability $(<0.3 \mathrm{~m} / \mathrm{d})$.

3) Saprolite soils: this unit is closely related with Porto granite weathering; most of these soils are kaolinitic silty sands with a very low permeability $(<0.1 \mathrm{~m} / \mathrm{d})$.

\section{Groundwater studies}

In order to understand how human activities may interfere with the chemical composition of this groundwater, sixteen sampling points were selected. The results of the physico-chemical analyses of local groundwater samples are presented in Table 1. From a hydrogeochemical point of view, most of the sampled groundwater presented nearneutral $\mathrm{pH}$ values (median $=6.8$ ), the lowest rate being 5.4 and the highest 7.9. Regarding the electrical conductivity (EC), most of the samples presented medium electrical conductivities $\left(\right.$ median $=434 \mu \mathrm{S} . \mathrm{cm}^{-1}$ ), with a minimum value of $369 \mu \mathrm{S} . \mathrm{cm}^{-1}$ and a maximum of $530 \mu \mathrm{S} . \mathrm{cm}^{-1}$. Concerning chemical signatures, the studied groundwaters show a wide range; cations are dominated by $\mathrm{Ca}^{2+}$ followed by $\mathrm{Na}^{+}$and $\mathrm{SO}_{4}{ }^{2-}$ and $\mathrm{Cl}^{-}$are the most important anions. By observing the Piper diagram of Figure 8 , one can conclude that most of the groundwater's are "mixed" $\mathrm{SO}_{4}^{2-} / \mathrm{Cl}^{-}-\mathrm{Ca}^{2+} / \mathrm{Na}^{+}$waters. All water samples have been analyzed for $\mathrm{NO}_{3}^{-}$, presenting a median value of $60 \mathrm{mg} / \mathrm{L}$, and displaying minimum and maximum values of 13 and
$86 \mathrm{mg} / \mathrm{L}$, respectively. According to the Portuguese and European legislations, the majority of these samples exceed the maximum admissible value $(50 \mathrm{mg} / \mathrm{L})$ for this element. The Wilcox diagram shows that these waters induce a low risk to alkalization and a medium risk to salinization (Figure 8). Afonso et al. (2007b) report a naturally low to moderate vulnerability to pollution of the Paranhos groundwaters. These spring groundwater have high concentrations of sulphate and nitrate, which may be due to sewage contamination.

\section{CONCLUDING REMARKS}

The crystalline substratum of the Porto urban area consists mainly of granitic rocks and sheared metagranitoids. The bedrock is weathered to different grades, altering erratically from fresh-rock mass to residual soil, showing highly variable geomechanical conditions. A large number of ancient shallow hand-made water galleries were excavated in the ground in the past six centuries. The underground topographic surveys performed on the Arca D'Água spring galleries (ca. 3,3 km long and $-21 \mathrm{~m}$ b.g.1.), mainly comprised rocky galleries, stone-walling galleries, masonry shafts, rocky and saprolite shafts.

The field hydrogeological study carried out at Arca D’Água spring galleries allowed to define a hydrogeotechnical zoning for the surrounding area of the catchworks. The groundwater flow of this area are in fissured hard rock comprising a weathered material zone that may have a high thickness. This soil-like layer seems to have an important role to the recharge of the groundwaters. Hydro-geophysical survey performed on Arca D'Água sector has shown evidences of anomalous structures underneath. The resistivity model suggested that granitic bedrock mass is more weathered in depth. Moreover, detected high-resistivity anomalies can be correlated with the Arca D’Água masonry reservoirs.

Table 1. Physico-chemical data for the 16 groundwater samples collected during the fieldwork campaign.

\begin{tabular}{|c|c|c|c|c|c|c|c|c|c|c|c|c|c|c|}
\hline $\begin{array}{c}\text { Sample } \\
\text { designation }\end{array}$ & $\begin{array}{c}\text { Site } \\
\text { description }\end{array}$ & $\begin{array}{c}E C \\
\left(\mu \mathrm{Cm}^{-1}\right)\end{array}$ & $\mathrm{pH}$ & $\begin{array}{c}\mathrm{Na} \\
\left(\mathrm{mg} \mathrm{L}^{-1}\right)\end{array}$ & $\begin{array}{c}\mathrm{K} \\
\left(\mathrm{mg} \mathrm{L}^{-1}\right)\end{array}$ & $\begin{array}{c}\mathrm{Ca} \\
\left(\mathrm{mg} \mathrm{L}^{-1}\right)\end{array}$ & $\begin{array}{c}\mathrm{Mg} \\
\left(\mathrm{mg} \mathrm{L}^{-1}\right)\end{array}$ & $\begin{array}{l}\mathrm{HCO}^{\mathrm{HCO}} \\
\left(\mathrm{mg} \mathrm{L}^{-1}\right)\end{array}$ & $\begin{array}{c}\mathrm{Cl} \\
\left(\mathrm{mg} \mathrm{L}^{-1}\right)\end{array}$ & $\begin{array}{l}\mathrm{SO}_{4} \\
\left(\mathrm{mg} \mathrm{L}^{-1}\right)\end{array}$ & $\begin{array}{l}\mathrm{SiO}_{2} \\
\left(\mathrm{mg} \mathrm{L}^{-1}\right)\end{array}$ & $\begin{array}{l}\mathrm{NO}_{3} \\
\left(\mathrm{mg} \mathrm{L}^{-1}\right)\end{array}$ & $\begin{array}{l}\mathrm{NO}_{2} \\
\left(\mu \mathrm{L}^{-1}\right)\end{array}$ & $\begin{array}{l}\mathrm{NH}_{4} \\
\left(\mathrm{mg} \mathrm{L}^{-1}\right)\end{array}$ \\
\hline $\mathrm{H} 1$ & ar & 435 & 5.5 & 32 & 9.7 & 35 & 5.4 & 39 & 35 & 66 & 6.6 & 57 & $<13$ & $<0.04$ \\
\hline $\mathrm{H} 2$ & ar & 423 & 5.4 & 32 & 9.8 & 31 & 4.8 & 16 & 38 & 65 & 6.5 & 64 & $<13$ & $<0.04$ \\
\hline $\mathrm{H} 3$ & g & 435 & 5.7 & 32 & 9.9 & 35 & 4.8 & 33 & 37 & 71 & 6.9 & 60 & $<13$ & 0.10 \\
\hline $\mathrm{H} 4$ & g & 437 & 5.9 & 33 & 9.8 & 33 & 4.8 & 32 & 37 & 68 & 6.1 & 59 & $<13$ & $<0.04$ \\
\hline H5 & g & 434 & 6.0 & 34 & 10.0 & 34 & 4.9 & 32 & 37 & 69 & 6.8 & 60 & $<13$ & $<0.04$ \\
\hline $\mathrm{H} 6$ & g & 434 & 6.4 & 33 & 10.0 & 35 & 4.8 & 32 & 37 & 69 & 6.9 & 60 & $<13$ & $<0.04$ \\
\hline $\mathrm{H} 7$ & g & 430 & 6.8 & 32 & 10.0 & 33 & 4.9 & 35 & 37 & 67 & 6.1 & 60 & $<13$ & $<0.04$ \\
\hline $\mathrm{H} 8$ & $g$ & 430 & 7.4 & 34 & 11.0 & 34 & 4.9 & 33 & 37 & 69 & 6.8 & 61 & $<13$ & $<0.04$ \\
\hline $\mathrm{H} 9$ & $\mathrm{~g}$ & 434 & 7.7 & 31 & 9.8 & 32 & 5.0 & 35 & 37 & 68 & 6.3 & 59 & $<13$ & $<0.04$ \\
\hline $\mathrm{H} 10$ & g & 434 & 7.7 & 32 & 9.6 & 33 & 5.0 & 34 & 37 & 69 & 6.2 & 60 & $<13$ & $<0.04$ \\
\hline $\mathrm{H} 11$ & g & 497 & 7.9 & 35 & 11.0 & 39 & 6.1 & 49 & 43 & 76 & 7.4 & 63 & 24 & $<0.04$ \\
\hline $\mathrm{H} 12$ & $r$ & 369 & 7.6 & 19 & 9.6 & 47 & 4.0 & 106 & 24 & 49 & 5.9 & 13 & $<13$ & $<0.04$ \\
\hline $\mathrm{H} 13$ & $r$ & 490 & 7.0 & 35 & 24.0 & 56 & 3.9 & 129 & 37 & 55 & 6.0 & 35 & 145 & 0.81 \\
\hline H14 & $r$ & 405 & 6.6 & 23 & 18.0 & 51 & 3.4 & 97 & 27 & 48 & 6.2 & 36 & $<13$ & $<0.04$ \\
\hline $\mathrm{H} 15$ & $r$ & 530 & 6.8 & 47 & 13.0 & 47 & 4.1 & 48 & 47 & 68 & 7.3 & 86 & $<13$ & $<0.04$ \\
\hline $\mathrm{H} 16$ & $r$ & 460 & 7.9 & 29 & 20.0 & 57 & 3.5 & 106 & 31 & 54 & 8.4 & 49 & $<13$ & $<0.04$ \\
\hline \multicolumn{2}{|c|}{ Median } & 434 & 6.8 & 32 & 10.0 & 35 & 4.8 & 35 & 37 & 68 & 6.6 & 60 & n.d. & n.d. \\
\hline \multicolumn{2}{|c|}{ Minimum } & 369 & 5.4 & 19 & 9.6 & 31 & 3.4 & 16 & 24 & 48 & 5.9 & 13 & $<13$ & $<0.04$ \\
\hline \multicolumn{2}{|c|}{ Maximum } & 530 & 7.9 & 47 & 24.0 & 57 & 6.1 & 129 & 47 & 76 & 8.4 & 86 & 145 & 0.81 \\
\hline
\end{tabular}

Site description: ar - Arca d'Água masonry reservoirs; g-granitic gutter pipe; $r$ - rock discontinuities; n.d. - not determined; EC - Electrical Conductivity. 


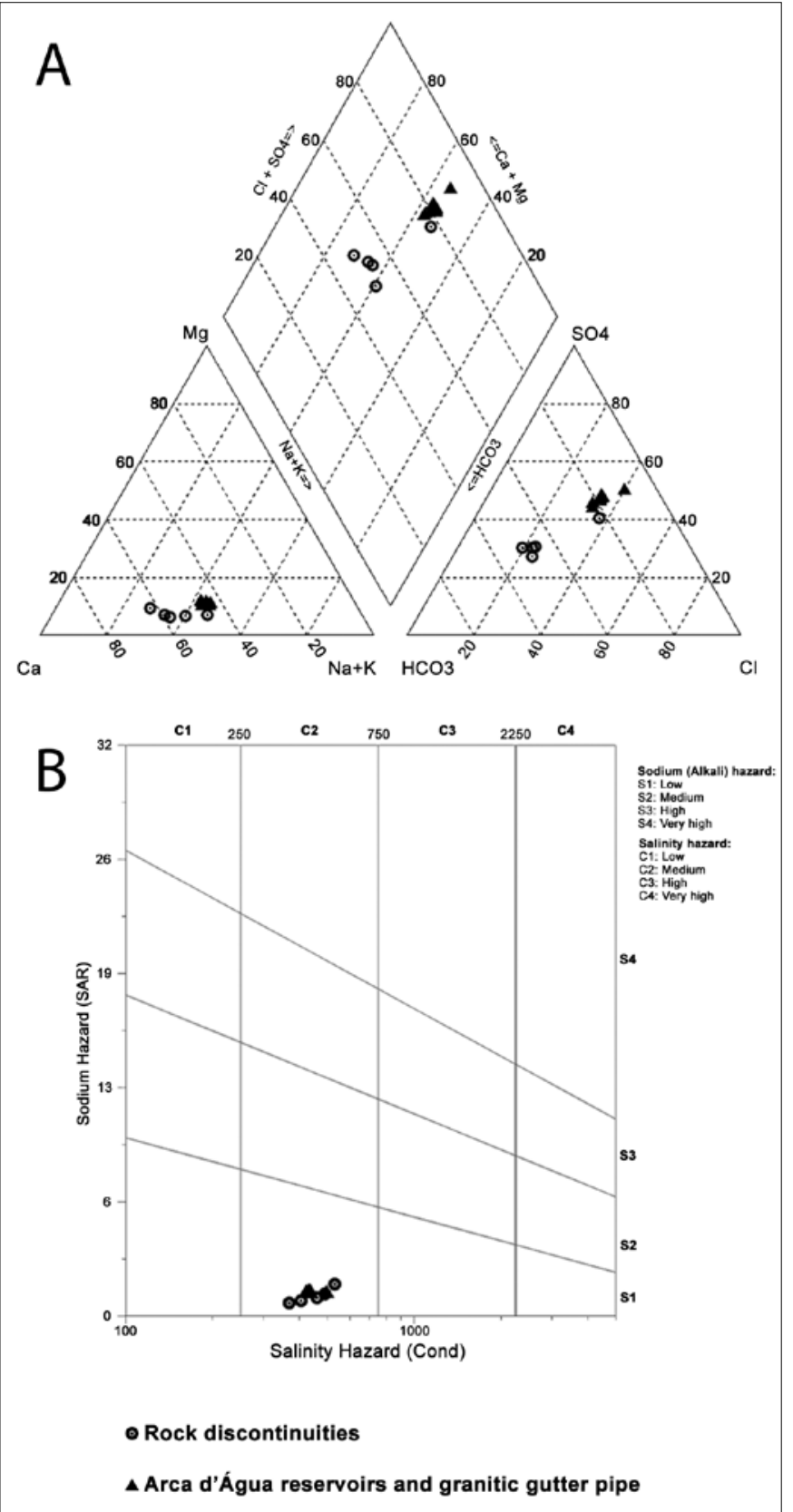

Fig. 8. Hydrogeological diagrams. Piper diagram (A) and Wilcox diagram (B) for the 16 water samples collected during the fieldwork campaign.

Hydrogeochemical analyses showed a nitrate and sulphate-enriched composition for these groundwaters, probably resulting from intense urbanisation, sewer leakage and some agricultural practices. The results obtained in this study suggest that some of the Porto urban groundwater can be suitable for irrigation uses, but additional tests must be carried out to verify its compliance with existing standards of quality. Specifically, geo-environmental studies are required to assess potential variations in water composition with seasonal changes in climate and human activities.

In recent years, a new theme has emerged among speleology in Europe (e.g., Italy, France, Spain and Greece, among others), the so-called urban speleology, urban caving and mining speleology (e.g., Day, 2002; Brick, 2009). This caving approach uses essentially mining topographic and speleological techniques and the spirit of cavers to the rediscovery of many forgotten underground structures made by mankind throughout his history. Frequently the urban speleologists support the development of scientific and geo-engineering studies or heritage projects related to scientific societies (e.g., documentary video named "subterranean Rome" by National Geographic, or the video "Retour à la Mine" from French Speleological School; Marchand \& Duseigne, 2007). In addition, speleologists are many times evolved in underground exploration and mapping of many structures that occur beneath cities. Different authors (e.g., Monteiro Santos \& Andrade Afonso, 2005; Frumkin \& Shimron, 2006; Brick, 2009) in diverse fields, mainly engineering, geotechnical, hydrogeology and environmental research, have mentioned the significance of detecting and locating ancient underground galleries or caves. Multidisciplinary approaches offers the best starting point for reliable speleological and geo-engineering studies (e.g., CERF, 1994; Day, 2002; Brick, 2009). Therefore combined reliable local data (underground topography, geology, hydrogeology, geophysics) in a geographical information system mapping environment, present a better understanding of the functioning of urban areas.

\section{ACKNOWLEDGMENTS}

This study was performed within the scope of the Groundurban ("Urban groundwater and environmental management in the Northwest Portugal") R\&D Project, which was funded by the Portuguese Foundation for Science and Technology (FCT) and FEDER EU funds, contract POCTI/CTE-GIN/59081/2004. Hidrourban ("Hydrogeology, geomechanics and geoconservation of ancient water-mines: contribution to the management of groundwater resources in urban and peri-urban areas" (Labcarga-IPP|PADInv'2007/08), also supported this work. Special acknowledgments are due to V. Beleza, R. Santos, M. Pinto, R. Sá, S. Ferreira and E. Pacheco for all the support. We acknowledge Mario Parise and Óscar Pueyo Anchuela for their constructive reviews that helped to improve the focus of the manuscript. In addition, we thank the editor Jo De Waele for all kind assistance.

\section{REFERENCES}

AES [Associação dos Espeleólogos de Sintra], 2008 - Relatório do levantamento topográfico do manancial de Paranhos, Porto. Associação dos Espeleólogos de Sintra, 6p. +11 maps. (Portuguese). Afonso M.J., Chaminé H.I., Carvalho J.M., Marques J.M., Gomes A., Araújo M.A., Fonseca P.E., Teixeira J., Marques da Silva M.A. \& Rocha F.T., 2007a - Urban groundwater resources: a case study of Porto City in northwest Portugal. In: Howard K.W.F., (Ed.), Urban Groundwater: meeting the challenge. International Association of Hydrogeologists Selected Papers. Taylor \& Francis Group, London, 8: 271-287.

Afonso M.J., Marques J.M., Guimarães L., Costa I., Teixeira J., Seabra C., Rocha F.T., Guilhermino L. \& Chaminé H.I., 2007b - Urban hydrogeology of the Paranhos sector, Porto city (NW Portugal): a geoenvironmental perspective. In: Chery L. \& Marsily G. (Eds.), Aquifer Systems Management: Darcy's Legacy in a World of Impending Water Shortage (E. Aquifer contamination studies, Chapter 29). Selected Papers on Hydrogeology, IAH/ Taylor \& Francis CRC Press, 1: 391-406. 
Almeida A., 2001 - Caracterização geoquímica e geocronológica do granito de duas micas sintectónico do Porto (NW de Portugal). In: Proceedings III ${ }^{\text {er }}$ Congreso Ibérico de Geoquímica. Instituto Tecnológico de Aragón, Zaragoza, p. 311-315. (Portuguese).

Alves J.F., 2005 - O abastecimento de água no quadro português: do modelo municipal ao multimunicipal. In: Águas do Douro e Paiva SA, Dez anos 1995-2005, Edição ADDP, Porto. p. 31-45. (Portuguese).

Amorim A.A. \& Pinto J.N., 2001 - Porto d'Agoa: Serviços Municipalizados de Águas e Saneamento do Porto, 197 p. (Portuguese).

Ashby T., 1935 - The aqueducts of ancient Rome. Clarendon Press, Oxford. 342p.

Assaad F.A., LaMoreaux P.E., Hughes T.H., Wangfang Z. \& Jordan H., 2004 - Field methods for geologists and hydrogeologists, Springer-Verlag, 420 p.

Babendererde S., Hoek E., Marinos P. \& Cardoso A.S., 2004 - Characterization of granite and the underground construction in metro do Porto, Portugal. In: Viana da Fonseca A. \& Mayne P.W. (Eds.), Proceedings ISC- 2 on Geotechnical and Geophysical Site Characterization, Millpress, Rotterdam, 1: 3948.

Begonha A. \& Sequeira Braga M.A., 2002 - Weathering of the Oporto granite: geotechnical and physical properties. Catena, 49: 57-76.

Bouguerra M.L., 2005 - Water: symbolism and culture. Les Rapports de 1' Institut Veolia Environnement, Paris, 5, 65 p.

Bourbon e Noronha T., 1885 - As aguas do Porto: Dissertação inaugural, Escola Médico-Cirúrgica do Porto, 89 p. (Portuguese).

Brick G., 2009 - Subterranean twin cities. University of Minnesota Press, 256 p.

Carrington da Costa J. \& Teixeira C., 1957 - Noticia explicativa da Carta Geológica de Portugal, na escala de 1/50000, Folha 9-C (Porto). Serviços Geológicos de Portugal, Lisboa. (Portuguese).

Carrington da Costa J., 1938 - O Pôrto: geografiageologia: In: Bastos C. (Org.). Nova Monografia do Porto. Companhia Portuguesa do Porto, p. 3-32. (Portuguese).

Carteado Mena J., 1908 - Contribuição para o estudo da Hygiene do Porto: analyse sanitaria do seu abastecimento em água potável. III. Estudo sobre os poços do Porto: Dissertação inaugural, Escola Médico-Cirúrgica do Porto, 270 p. (Portuguese).

CERF [Civil Engineering Research Foundation], 1994 Geo-engineering: a vision for the $21^{\text {st }}$ Century. CERF Report \#94-5020, Washington, 40 p.

CFCFF [Committee on Fracture Characterization and Fluid Flow], 1996 - Rock fractures and fluid flow: contemporary understanding and applications. National Research Council, National Academy Press, 568 p.

Chaminé H.I., Gama Pereira L.C., Fonseca P.E., Noronha F. \& Lemos de Sousa M.J., 2003a - Tectonoestratigrafia da faixa de cisalhamento de Porto-Albergaria-aVelha-Coimbra-Tomar, entre as Zonas Centro-Ibérica $e$ de Ossa-Morena (Maciço Ibérico, $W$ de Portugal). Cadernos Laboratório Xeolóxico de Laxe, A Coruña, 28: 37-78. (Portuguese).
Chaminé H.I., Gama Pereira L.C., Fonseca P.E., Moço L.P., Fernandes J.P., Rocha F.T., Flores D., Pinto de Jesus A., Gomes C., Soares de Andrade A.A. \& Araújo A., 2003b - Tectonostratigraphy of middle and upper Palaeozoic black shales from the Porto-Tomar-Ferreira do Alentejo shear zone (W Portugal): new perspectives on the Iberian Massif. Geobios, 36(6): 649-663.

Chilton J., 1997 - Groundwater in the urban environment, selected city profiles. A.A. Balkema, 342 p.

Chilton J., 1999 - Groundwater in the urban environment, problems, process and management. A.A. Balkema, $682 \mathrm{p}$.

CMP [Câmara Municipal do Porto], 1932 - "Vereaçoens" - anos de 1390-1395. Documentos e memórias para a história do Pôrto, Publicações da Câmara Municipal do Porto 2: 145-146. (Portuguese).

COBA [Consultores de Engenharia e Ambiente, SA], 2003 - Carta geotécnica do Porto. $2^{\text {a }}$ edição, COBA/ FCUP/CMP, 230 p.+ maps. (Portuguese).

D'Andrade Junior A., 1895 - Breves apontamentos sobre aguas de poços do Porto. Dissertação inaugural, Escola Médico-Cirúrgica do Porto, 65 p. (Portuguese).

Day A.J., 2002 - Cave surveying. British Cave Research Association, Buxton, Cave Studies Series, 11, 40 p.

de Oliveira Marques A.H., 1972 - History of Portugal, from Lusitania to Empire. Columbia University Press, New York, 1, 507 p.

Edwards L.S., 1977 - A modified pseudosection for resistivity and induced polarization. Geophysics, 42: 1020-1036.

El-Qady G., Hafez M., Abdalla M.A. \& Ushijima K., 2005 Imaging subsurface cavities using geoelectric tomography and ground-penetrating radar. Journal of Cave and Karst Studies, 67(3): 174-181.

Ferreira da Silva A.J., 1889 - Contribuições para a hygiene da cidade do Porto. Typ. António José da Silva Teixeira, Porto, 263 p. (Portuguese).

Fontes A., 1908 - Contribuição para a hygiene do Porto: analyse sanitaria do seu abastecimento em água potável. I. Estudo dos Mananciais de Paranhos e Salgueiros. Dissertação inaugural, Escola Médico-Cirúrgica do Porto, 172 p. (Portuguese).

Foster S., Morris B., Lawrence A. \& Chilton J., 1999 Groundwater impacts and issues in developing cities: an introductory review. In: Chilton J., (Eds.), Proceedings of the $27^{\text {th }}$ IAH Congress on groundwater in the urban environment: Selected cities profiles. Balkema, Rotterdam, 21: 3-16.

Frumkin A. \& Shimron A., 2006 - Tunnel engineering in the Iron Age: geoarchaeology of the Siloam Tunnel, Jerusalem. Journal of Archaeological Science, 33: 227-237.

Gaj F., Guglielmetti V., Grasso P. \& Giacomin G., 2003 Experience on Porto, EPB follow-up. Tunnels \& Tunnelling International, 35(12): 15-18.

Garden J.W., 2005 - Historical development of water and sanitation services. In: Petri S.J. \& Tapio S.K., (Eds.), Water, Time and European Cities: history matters for the Futures. WaterTime Project, European Commission, p. 25-50.

Gavand E.H., 1864 - Estudo sobre o abastecimento d'agua da cidade do Porto. Relatório apresentado à Câmara Municipal do Porto, 143 p. (Portuguese). 
Gomes A., Chaminé H.I., Teixeira J., Fonseca P.E., Gama Pereira L.C., Pinto de Jesus A., Pérez Albertí A., Araújo M.A., Coelho A., Soares de Andrade A. \& Rocha F.T., 2007 - Late Cenozoic basin opening in relation to major strike-slip faulting along the Porto-Coimbra-Tomar fault zone (northern Portugal). In: Nichols G., Williams E. \& Paola C., (Eds.), Sedimentary Processes, Environments and Basins: a tribute to Peter Friend. Special Publications of the International Association Sedimentologists (IAS), Blackwell Publishing, 38: 137-153.

Guedes A.M., 1917 - Saneamento do Porto, a canalização dos esgotos, o abastecimento das águas. Dissertação inaugural, Escola Médico-Cirúrgica do Porto. (Portuguese).

Hodge A.T., 1992 - Roman aqueducts and water supply. Duckworth, London, 504 p.

IAEG [Commission on Engineering Geological Mapping], 1981 - Rock and soil description and classification for engineering geological mapping. Bulletin of Engineering Geology and the Environment, 24: 235-274.

INE [Instituto Nacional de Estatística], 2008 - Statistical information about Portuguese population: Porto city. http://www.ine.pt/ (accessed July 2009)

ISRM [International Society for Rock Mechanics], 1978 - Suggested methods for the quantitative description of discontinuities in rock masses. International Journal of Rock Mechanics and Mining Science \& Geomechanics Abstracts, 15(6): 319-368.

ISRM [International Society for Rock Mechanics], 1981 - Basic geotechnical description of rock masses. International Journal of Rock Mechanics and Mining Science \& Geomechanics Abstracts, 18: 85-110.

ISRM [International Society for Rock Mechanics], 2007 - The complete ISRM suggested methods for characterization, testing and monitoring, 1974-2006. In: Ulusay R. \& Hudson J.A., (Eds.), suggested methods prepared by the commission on testing methods, ISRM Ankara, Turkey, 628 p.

Johnson L.E., 2009 - Geographic information systems in water resources engineering. CRC Press, Taylor \& Francis Group, Boca Raton, 298p.

Koloski-Ostrow A.O. (Ed.), 2001 - Water use and hydraulics in the roman city. Colloquium and Conference Papers Series of the Archeological Institute of America. Kendall-Hunt Publishing Company, Iowa, 3, $131 \mathrm{p}$.

Legget R.F., 1973 - Cities and geology. McGraw-Hill, New York, 624 p.

Lerner D.N. 2004 - Urban groundwater pollution. A.A. Balkema, $277 \mathrm{p}$.

Lima O., 1936 - Os lavadouros públicos do Pôrto. Boletim de Higiene e Sanidade Municipais, Câmara Municipal do Porto, 3: 3-15. (Portuguese).

Marchand F. \& Duseigne V., 2007 - Retour à la mine (video). L’École Française de Spéléologie, Fédération Française de Spéléologie, http://efs.ffspeleo.fr/mines/ mines.htm (accessed July 16, 2009).

McCall G.J., Demulder E. \& Marker B.R., 1996 - Urban geoscience. AGID Special Publication Series, Taylor \& Francis, Rotterdam, 20, 279 p.
Monteiro Santos F.A. \& Andrade Afonso A.R., 2005 Detection and $2 d$ modelling of cavities using poledipole array. Environmental Geology, 48: 108-116.

Monteiro Santos F.A., Andrade Afonso A.R. \& Dupis A., 2007 - 2-D joint inversion of $d c$ and scalar audiomagnetotelluric data in the evaluation of low enthalpy geothermal fields. Journal of Geophysics and Engineering, 4: 53-62.

Mulder E.F.J., McCall G.J.H. \& Marker B.R., 2001 Geosciences for urban planning and management. In: Marinos P.G., Koukis G.C., Tsiambaos G.C. \& Stournaras G.C., (Eds.), Proceedings International Symposium on Engineering Geology and the Environment, Balkema, Rotterdam, 4: 3417-3438.

Parise M., Bixio R., Burri E., Caloi V., Del Prete S., Galeazzi C., Germani C., Guglia P., Meneghini M., \& Sammarco M., 2009 - The map of ancient underground aqueducts: a nation-wide project by the Italian Speleological Society. Proceedings $15^{\text {th }}$ International Congress of Speleology, Kerrville (Texas, USA), 3: 2027-2032.

Pereira E., Ribeiro A., Carvalho G.S., Noronha F., Ferreira N. \& Monteiro J.H., 1989 - Carta Geológica de Portugal, escala 1/200000, Folha 1. Serviços Geológicos de Portugal, Lisbon. (Portuguese).

Petri J., KatkoT.S. \& Vuorinen H.S., 2007 - Environmental history of water: global views on community water supply and sanitation. IWA Publishing, London, 629 p.

Rebelo da Costa A., 1788 - Descrição topográfica e histórica da cidade do Porto. $3^{\mathrm{a}}$ edição (fac-simile), Editora Frenesi, Lisboa. 273 p. (Portuguese).

Ribeiro A., Munhá J., Dias R., Mateus A., Pereira E., Ribeiro L., Fonseca P.E., Araújo A., Oliveira J.T., Romão J., Chaminé H.I., Coke C. \& Pedro J., 2007 - Geodynamic evolution of the SW Europe Variscides. Tectonics, 26, $\mathrm{n}^{\circ}$ TC6009, 24 p.

Richard B., 1977 - An overview of cavity detection methods. Book of Abstracts of the symposium on detection of subsurface cavities, p. 44-79.

Sharpe D., 1849 - On the Geology of the neighbourhood of Oporto, including the Silurian coal and slates of Vallongo. Quarterly Journal Geological Society of London Proceedings, 5: 142-153.

Silva A.F., 2004 - Problems of agency and technological issues in the municipalisation of water supply systems, Portugal (1850-1930). Seventh International Conference on Urban History: European City in Comparative Perspective, Athens. p. 1-35.

Silva A.F. \& Matos A.C., 2004 - The networked city: managing power and water utilities in Portugal, 1850s-1920s. Business and Economic History OnLine, 2: 1-45.

Silva G., 2000 - Fontes e chafarizes do Porto. Serviços Municipalizados de Águas e Saneamento do Porto, SMAS, Porto. 246 p. (Portuguese).

Sousa Reis H.D., 1867 - Mappa synoptico estatisticohistorico dos mananciaes publicos d'esta antiga, mui nobre, sempre leal e invicta cidade do Porto. Porto, 58 p. (Portuguese). 